\title{
Proceeding
}

Supplementary Issue: Autumn Conferences of Sports Science. Costa Blanca Sports Science Events, 18-19 December 2020. Alicante, Spain.

\section{Motor learning for the developmental age in coded spaces and times}

\author{
DANIELE COCO 14 , ROBERTO COPPOLA², ROSARIA SCHEMBRI ${ }^{2}$, FRANCESCO CASOLO ${ }^{3}$ \\ ${ }^{1}$ Department of Education, University "Roma Tre", Rome, Italy \\ ${ }^{2}$ Faculty of Human and Society Sciences, University of Enna "Kore", Enna, Italy \\ ${ }^{3}$ Faculty of Educational Sciences, Catholic University of "Sacred Heart", Milan, Italy
}

\begin{abstract}
The traditional teaching methods linked to motor education and based on the canonical transmission of knowledge and learning are now outdated. In fact, we could say that we emphasize all forms of learning that have a dynamic and concrete development in which all children can have a role as a 'protagonist'. The school increasingly conditioned by continuous social changes, cannot be lived only as a place of duplication and transmission of knowledge, but can be lived and organized as a space of creativity, fun and emotion as well as imagination also motor. "This teaching practice is often hampered by the school organization of places and times and by the training of teachers' skills" (Lipoma, 2014, p.201). The environment, therefore, must be organized and structured according to the needs of children and their age groups, full of materials, large and small tools where it is possible, however, above all to make concrete experiences experiencing successes and failures in a safe environment. Another fundamental element that distinguishes the success of motor learning is the time dedicated to the movement that lately is reduced and of little quality. "The time devoted to recreational activities has decreased and this is found not only in the school but also in moments of extraschool leisure where you notice the increase of games "sedentary" to the detriment of those engines" (Casolo, 2019, p.495).
\end{abstract}

Keywords: Motor learning; Developmental age; Spaces; Times; Outdoor education.

\section{Cite this article as:}

Coco, D., Coppola, R., Schembri, R., \& Casolo, F. (2021). Motor learning for the developmental age in coded spaces and times. Journal of Human Sport and Exercise, 16(2proc), S788-S800. doi:https://doi.org/10.14198/ihse.2021.16.Proc2.65

Corresponding author. Department of Education, University "Roma Tre", Via del Castro Pretorio 20, cap. 00185 Rome, Italy. E-mail: daniele.coco@uniroma3.it

Abstract submitted to: Autumn Conferences of Sports Science. Costa Blanca Sports Science Events, 18-19 December 2020. Alicante, Spain.

JOURNAL OF HUMAN SPORT \& EXERCISE ISSN 1988-5202

(c) Faculty of Education. University of Alicante

doi:10.14198/jhse.2021.16.Proc2.65

S788 | 2021| Proc2 | VOLUME 16

C 2021 University of Alicante 


\section{INTRODUCTION}

Cities represent the paradigm of living today through their temporal space elements. Nowadays, the symbolic environments of relationships and aggregation such as squares, churches, museums, theatres and libraries have been rationalized and functionalized making sure that the new metropolitan generations are surrounded by empty and fragmentary spaces and times.

Similarly, the time devoted to recreational activities has decreased and this is found not only in school and out-of-school, but also in leisure time (Vago, et al., 2015b). One of the many causes of this phenomenon is the lack of safe and protected outdoor spaces. In the re-education to the re-appropriation of space and time, the school is placed in an advantageous situation to fulfil this "mission" as it is the privileged context to develop motor learning (Tortella, et al., 2016). It is therefore necessary to organize a school setting by planning every single training moment, using suitable materials and equipment also using systems that use digital technologies for the evaluation of movement in physical education and in motor and sports sciences. We will observe in which spaces and times it is possible to propose motor activities and with what characteristics, from indoor to outdoor school environments.

Spatiality is a property of human existence and space influences behaviours and emotions: each mode of interaction between individuals is characterized and conditioned by the spatial matrix in which it expresses itself, by the distances between subjects. Space is never neutral or objective, therefore it cannot be perceived in the same way by different people. Every subject thinks it, lives it differently because every society, every culture, every group processes it mentally and emotionally according to different images, representations, needs and uses (Parricchi, 2019 p.385).

"The educational environment, in other words, must be an inhabited space and not immediately, a place that involves the body in action, participation, research and discovery, a real facilitator of action, which guides and supports personal learning experiences" (Ceciliani, 2019. p.117). The consequences of this continuous, orderly and for all children can be traced back to three main areas such as: "the one aimed at the prevention of certain pathological situations that are particularly recurrent today, a second that examines the state of form and well-being of the child, and finally that which studies the contribution of movement in the process of maturation of the cognitive system with its implications on school learning and self-control" (Casolo, \& Coco, 2019, p.38).

"If we consider space as an educational space, that is, as an environment in which intentional relationships take place, privileged dimensions of encounter between subjects, we can affirm that it exists only after educational events that occur in it. But the educational meeting can take place in countless spaces, therefore it is not possible a topological identification of the educational space because every place of the space can become an educational place" (Alberici, 2002). Recent research is moving to recover the link of well-being with the physicality of the school (Weyland, \& Attia, 2015) using the similarity with the individual: the body that the school has, the body that tells of habits and lifestyles, quality and commitment. Buildings intended for education and training are environments in which the human being lives, which like others have the task of expressing their purpose through their materiality. Spaces also convey and codify information about the relationships of bodies in space, the relationship between bodies and space, and between the identities of bodies that enter into relationship (Gennari, 1997). 


\section{METHOD}

The aim of the work presented here is to reflect and analyse the characteristics in which motor activities are presented in different environments and times. It has been observed how the different urban changes have influenced the lifestyles reducing times and remodulating the spaces including the world of the school and the way of doing didactics. The literature survey was carried out by national and international databases such as Google Scholar, OCLC Worldcat and EBSCO Publishing and deepening the topic in some scientific journals of pedagogical, educational and motor and sports education. The keywords used for this research were: Space, time, learning Motor, school, outdoor education. Found in titles and abstracts of various scientific contributions plus additional filters were applied to narrow the results and make them more specific. Other filters have also been included, for example in the language (English) and the year of publication of the scientific contribution starting from the historical pedagogists to the most modern ones. The search results have been divided into areas of interest:

Urban space; urban time; space where you can practice motor activities divided into indoor and outdoor school environment; time related to the development of learning through motor and sports education at school.

\section{RESULTS}

\section{The importance of space and time in the urban context}

Cities and schools represent the paradigm of today's life, through their space-time elements, which never as today assumes a very important symbolic and identity value that unfortunately is being lost. This depersonalization of urban and educational places has not always been so, as well as being a consequence of the rationalization and functionalization of spaces is the result of the loss of the times in which finding yourself in a shared space and time represented a ritual, a healthy habit that cannot be renounced. In this scenario of indecipherability of today's contexts, emerges the pedagogical need to train and rediscover the ability to stay in time and time by identifying educational routes urban and non-urban that allow to reconstitute categories of meaning.

Time and space have a fundamental role in the formation of man (Notarnicola, et al., 2012). Everything that concerns its existential path takes place in a place and in a time that is why today the progressive impoverishment of the meaning of the space-time axes is a source of unease. The new metropolitan generations are surrounded by empty and fragmentary spaces and times.

More and more the new generations are subject to live the daily life in spaces and predefined times that mark their own rhythms of life, environments more and more codified in a well-defined timing.

In this sense it is possible to outline some educational commitments that effectively cross the value of the city (Perla, 2002, pp.43-44):

- Recover the centrality of the symbolic public places of the meeting, with their historical-cultural and value;

- Legitimize and restore communicative depth to the traditional public places of interpersonal communication (squares, historic centres, churches), spreading a culture of relationship, conviviality, solidarity;

- Enhancing the use of modern symbolic communication sites, such as libraries, bookshops and museums, as well as green areas or play and sport areas, theatres and cinemas; 
- Encourage the enjoyment of places where "neighbourhood communities" are created, then streets and courtyards;

- Semantize non-places, subjecting them to multiple uses.

It goes without saying that because of the deep interconnection that characterizes them, reorganizing the spaces requires an equally significant reorganization of the times. Time is not a marginal element, slow rhythms and relaxed times foster that sense of duration and continuity that you need to decipher spaces, refine their perception, cultivate thoughts, build symbols, create complex mental landscapes and live in a complex way even the real ones.

Regaining the sense of time is a fundamental condition for the new generations to learn to reclaim spaces. This can be achieved through an educational path aimed at rediscovering the symbolic value of public meeting places and return for example public spaces, squares, playgrounds the relational role and convivial role of the past.

Time and space are concepts around which we build not only the lives of human beings but also of entire societies, just think of the fact that each individual, animating with his being the space that surrounds him shapes him to his needs. The relationship between the individual and the surrounding space is constantly changing as each individual processes it according to different needs, representations and uses.

What unites adults and children, however, is that at different levels, both attribute to the places an emotional connotation and or an emotional value.

\section{Learning environments between time and space}

The school, for example, has a temporal and spatial location in which educational relations are carried out.

Behind every space built for education there are history and ideology that inspired school architecture.

During the twentieth century, the industrial society promoted a school building structure that was never questioned in its functional and symbolic aspects.

It is therefore indisputable the awareness that educational spaces are essential references for learning and teaching. The spaces in fact represent a fundamental component of school activities, characterizing the educational contexts that take place inside. In the school "space is the architecture of teaching [...] not only topology, but prossemics of teaching" (Damiano, 2013, p.71).

When we talk about school spaces we do not mean only physical ones, but we refer to internal, individual and group and learning ones. In this sense, the concept of action takes over as the fulcrum between subjects, environment and objectives, thanks to which it is possible to move from the space of action to that of knowledge.

It is this process that produces learning, which in turn becomes "the process through which the subject transforms himself, while he transforms the world" (Rossi, 2009, p.57).

The next reflection shifts the attention of how the school spaces can be understood as environments for learning, to allow each student to activate their own processes of building knowledge; group, to encourage exchanges and forms of collaboration through the use of suitable teaching techniques; exploration in order 
to trigger the circuit observation-experimentation-manipulation of knowledge inside and outside the classroom.

Therefore, the opportunity emerges to try to understand how the configuration and the preparation of a space other than the classroom can encourage the realization of genuinely significant experiences that, resuming the inter-action between subjects and with the elements of the context to favour the process of construction of knowledge within a framework of situated experiences.

Just as not all experiences are educational, so not all spaces educate; For spaces to take on the profile of environments capable of stimulating the activation of learning pathways, they must allow access to and manipulation of knowledge and encourage the possibility of asking questions rather than providing answers. capable of initiating direct paths of knowledge that pass through the sensory, involving the subject in a global way in all its languages, motor, symbolic, representative, which support knowledge circuits oriented to exploration and experimentation, that encourage the acquisition of autonomy. Exclusive character cover the outdoor activities in which the individual is involved in an important way at the level of their own body. The outdoor activities place the subjects in danger, force them to leave their safe zone, activating, thus, processes of progressive achievement of the different autonomies not only motor, but also related to the emotional selfregulation (Carpi, 2017).

Outdoor activities have the advantage of reducing stress, promoting concentration, making the individual experience the physical limit encouraging him to be autonomous to seek more and more contact with nature.

The pedagogist Mlinarević (Isenberg \& Jalongo, 1997) believes that in structuring this environment the educator should follow the following five criteria:

1. The child's perception of desirable behaviour (message sent to the child on whether or not there is free interaction with the environment and materials offered);

2. Ease in controlling the environment (it allows the educator to follow the activities of all children to meet the different needs of each);

3. Accessibility of materials (open shelves, toys and teaching tools at hand to make the child feel at ease, increase his sense of belonging to the environment and the readiness to use the materials available to solve problems)

4. Different perception of space (based on the difference between adults and children in the amount of experience, body proportions, eye level, etc.);

5. Free movement in space (absence of obstacles to reduce the number of conflicts, interference in the activities of others and increase the sense of security).

Designing a school requires the realization of a living space in which it is possible to connect pedagogy, architecture, sociology and anthropology, disciplines and knowledge called to declare their epistemologies, compare their languages and symbolic systems in a new freedom that arises from the will of confrontation and dialogue. We must seize every opportunity offered by the links between architecture, pedagogy and other disciplines to create better spaces, completer and more suitable for various educational activities. The spaces, moreover, communicate and define indications about the relations of the bodies in the space that is being lived, the relationship between the bodies and the space and between the identities of the bodies that enter in relation to each other in an authentic way (Gennari, 1997). The space must allow the child to relate to others, to make choices, to experiment and explore. In addition, it must encourage reflection to allow the child to be a protagonist, to learn to know each other, to establish a relationship of trust with himself and with others, reflecting on his own actions. The nodal centre of the classroom in a recent past was the chair, 
understood as a real pole of command, raised compared to the rest of the furniture to allow to exercise vigilance and provide for possible sanctions with the aim of ensuring social discipline of the bodies (Foucault, 1975).

It will also be necessary to identify new spatial concepts, new space subdivision models, new usage and experience profiles, to improve the functional quality of a new school in a sustainable and reasonable way (Weyland, et al., 2019).

The environment in which you learn must be pleasant, make the child feel at ease, make it possible to exchange ideas, offer security, happiness, fun and emotion. The importance of the aesthetic dimension is also considerable, which becomes a pedagogical quality of the school space (Malaguzzi, 2004, 2010; Miljak, 2009).

The construction and organization of space in the school must allow (Ceppi, \& Zini, 1998; Frabboni, 1992):

1) The child to: express his potential, curiosity, skills; explore, research alone and with others; strengthen his identity, autonomy and security; be able to communicate with other his peers; see respected his identity and privacy;

2) The educator to: feel integrated in the relationship with children and parents; feel supported in the realization, organization and archiving of projects; be recognized in their need for privacy; have the opportunity to meet with experts, colleagues and parents in appropriate spaces and furnishings; being supported in the process of professional training and refresher;

3) The parent to be welcomed, informed and to be able to collaborate and meet with other parents and educators.

The school enjoys an advantageous situation to fulfil this "mission" as it is the privileged context for the implementation of educational interventions: allows it to reach virtually the entire population of young people who are beginning to choose and adopt lifestyles. The quality of the spaces therefore coincides with the quality of learning, Malaguzzi (2010) defined the space as "third educator", this definition becomes indispensable only if combined with the value given to educators and the collaboration of parents, That's the only way this axis becomes a winner. The school, in cooperation with the family helps the child to express all its potential, consequently, the environment must be welcoming, beautiful, pleasant, lovable, cared for, colourful and rich in materials and equipment that encourage children to work with pleasure by experimenting (Coco, 2016). The heart of education, is the structural device, understood as the spatial dimension, the temporal one, the corporal one and the symbolic one that determines human experience. This means that every educational experience ultimately depends on the structuring of space, time, body and symbol and the relationship that each of these material dimensions entertains with others (Ferrante, \& Santori, 2011).

\section{DISCUSSION}

\section{The value of time in motor education}

In order to realize the realisation of motor and sports activities, especially in the school context, it will be necessary to accept a culture of corporeity (Coco, 2015) welcoming it fully in the system of transmission of knowledge in the relationship between teacher and learner (Fischetti, Latino, Cataldi, \& Greco, 2020). The structuring of the spatial and temporal dimensions in the school system, if well organized, can bring important results in the learning of the pupils (Haga, et al., 2018). "The time devoted to the recreational-motor activity has decreased and this is found not only in the school but also in moments of extra-school free time where you notice the increase of games "sedentary" to the detriment of those engines. The causes of this situation 
are many but the most significant are believed to be: 1) the advent of electronic games, now intriguing and interesting in the child more than movement games as well as being less tiring; 2) the lack of safe and protected outdoor spaces as the old "courtyards" today serve as car parks; 3) the lack of motor proposals in the school system where today there is no real education to movement and where it is still believed that games should be used only for moments of recreation" (Casolo, 2019, p.945). In all the industrialized areas of the world there is an urgent need of adequate programs and motor activity projects also for a prevention and a public health priority that is increasingly manifested. The World Health Organization has defined health promotion as the process by which people's control is increased and health is improved through multidimensional intervention to propose policy actions, social and educational that could strengthen public awareness of health and encourage healthy lifestyles also through the enhancement of motor-sports activities (Coco, Tortella, \& Casolo, 2020). An adequate amount of movement, which for the WHO is equivalent to at least 60 minutes per day of Physical Activity (D'Elia, 2019) it is recommended not only to feel good physically but also to encourage the development of relational, cognitive, moral and self-control skills in children (Coco, 2014). With the aim of identifying the organizational strategies to achieve this goal we will now try to take stock of opportunities and stimuli to movement activities that in primary school can be induced by adequate planning (Casolo, \& Coco, 2019), predisposition and organization of spaces as physical environments (classrooms, gyms, natural environment) and school times. The school planning and in particular the hours dedicated to physical education (Galvani, et al., 2017) and motor curriculum are 2 hours per week. We believe that, unfortunately, this is not the best situation, especially if one were to consider that less is actually being done in many cases. The ministerial guidelines for the primary school curriculum of 2012 give us an appropriate indication of the OAS of the movement that concern four areas: 1) The body and its relationship with space and time; 2) The language of the body as a communicative/expressive mode; 3) The game sports rules and fair play; 4) Health and well-being prevention and safety. As we initially mentioned, the family plays a very important role in the education of its children to the movement and through the movement but the time that parents devote to the education of children is progressively decreasing but above all in a less effective way. In times when you are together, the use of elements such as mobile phones, tablets and television that drive away the relationship and communication at home and away from home.

Among the games handed down from grandparents to parents first and grandchildren then, the games of movement are those that, in the period that includes our last two generations, are progressively decreasing or even disappearing. The times of practice for these games coincides with the free time of adults which is unfortunately less and less. Human evolutionary development encompasses the so-called endogenous or uniqueness-dependent factors and bio-diversity of individuals as characterizing elements of man, such as genetic characteristics, level of knowledge and capacity, past experiences and those exogenous or dependent on the environment outside the individual including the social environment (Caprara, Steca, Gerbino, Paciello, \& Vecchio, 2005) but also the spaces in which the different forms of learning are organized. These spaces are decisive in favouring or not the activities of movement, both playful-free and / semistructured and sporty.

\section{The value of indoor space in motor learning}

In the educational context, the Physical-Sports Education (Pignato, Coppola, \& Manzo, 2016) is, even today, identified as the gaming discipline par excellence, with strong aggregating and relational value, but underestimated in relation to the ability to contribute significantly to the realization of the educational relapse. Movement education must be understood as learning to move, with the acquisition of skills and skills related to body knowledge and coordination concepts (Montesano, 2018), spatial-temporal organisation, control of movements and must relate to the concept of move for learning, so as to facilitate the acquisition of social skills, the management of cooperation and competition (Sgrò, Nicolosi, Schembri, Pavone, \& Lipoma, 2015). 
Positive repercussions for individual and collective growth, to support the social and health value of motor activity and sport, to promote the aggregative phenomena that arise within sports groups, to stimulate cathartic activity, through play, and well-being necessary to establish new relationships, including emotional.

By means of the movement, man finds himself in the society in which he lives, in the world; in fact, he becomes capable of being placed in and with the world in the making. In fact, we can say that the human being is and exists with his own body movement that evolves and improves over time. "Man is a reality in motion and not static. The body movement evolves along with the movement of the world, in which the original desires and intuitions give rise to the genesis of thought from which the intellectual dimension of the human being and the active personality engaged with the world around him gradually flows.

Through the movements and actions of his body, the human being manifests his own existence, the need and the desire to live. Starting from an inner world he opens effectively to an outer world" (Simonetti, 2013, p.188). This relationship between interior and exterior allows us to dialogue with others on our own, with the world, with other human beings. Motor and sports education at school: "it has its own particular teaching, which cannot disregard the fact of being a practical discipline, which "acts" on the field. The teaching consists in giving a series of stimuli to provoke certain responses, in a continuous interaction between stimulation (the educational action of the teacher) and adequate responses (the motor actions of the pupils) that, initially global and spontaneous, should become increasingly analytical, controlled and finalized" (laschi, 1995, p.124). Therefore, motor and sports activities can provide the student with different opportunities to reflect on: "cognitive, social, cultural and emotional experiences. Through the movement, with which a wide range of gestures ranging from facial expression to the most varied sports performances, the pupil will be able to explore the space, know his own body, communicate and relate with others" (Ministry of Education, 2007, p.73).

The school spaces dedicated to motor and sports education today deserve some specific reflections, these involve mainly but not only the "gym". Place of worship for lovers of sneakers to perform hours of motor education, but also for all those activities that require large numbers and lots of space.

Some conditions that must be in the gym environment to ensure hygiene and functionality are to be a safe environment, be hygienically clean and be well equipped with even innovative technological systems. Unfortunately, however, there are several factors that prevent the linear course of the lesson, many school gyms are: without emergency exits; improvised places whose initial origin was a closet or a basement; spaces with central columns; with radiators, steps, doors, protruding windows without protective padding; with old and worn floors; many places are full of infiltrations and draughts; the equipment is dusty and has no typeapproval or adequate documentation of the current standards; no adequate air recirculation; little light. The presence of adequate equipment is essential even if in Italian public elementary schools, it is often lacking especially with regard to small tools and carpets. The availability of suitable and preparatory environments and equipment can only facilitate the learning of skills (Montella, Ceciliani, Morsanuto, Federici, \& Altavilla, 2019). In addition to the traditional gym equipment that is usually divided into large tools (wall bars; Swedish framework: climb stage, vertical stairs, horizontal ladder, boards and balance beam, pony, small and large mattresses) and small tools (filled balls or «medicine balls», light balls, tennis balls, ropes, logs; reek and boards; hoops: clubs) each teacher can add any other unconventional tool. The validity of a tool is linked to the possibility that it has to offer ideas, suggest insights, to lend itself as a tool for creativity and the expression of something truly personal (Calvesi, et al., 1998). 


\section{The value of outdoor space in motor learning}

In addition, there may also be other spaces, large size, usable for the activities of movement and bodily expressiveness, such as corridors, halls, or, the individual classrooms, modified in the arrangement of chairs, Benches, cabinets and chair that with the right safety-related changes can be transformed into small gyms. Often school buildings have a more or less wide natural environment, consisting of gardens, courtyards, with trees and native plants, these spaces allow you to become an open-air gym (Tortella, Haga, Ingebrigtsen, Sigmundsson, \& Fumagalli, 2019), where it is possible to express to the maximum all the unexpressed potentialities in other contexts of the pupils during the hours of motor and sport education (Sgrò, et al., 2017).

We could say that there is a real need to return to nature, to outdoor environments especially in urban agglomerations with few green areas. In literature numerous publications that support the need for the child to live experiences in the natural environment (Farnè, 2010; Ceciliani, 2016; Monti et al., 2017). Outdoor education therefore becomes a space-time context that can be used today by teachers when weather conditions allow it, but also to discover and experience activities related to climate conditions. The historical preconceived of this form of movement was the French Hébert (1936). The proposed activities range from proposals on the main basic engine schemes such as walking, running, jumping, climbing, balance, pushing, pulling, lifting, bring, launch, attack and defend to the execution of moments of collective activity as the execution of coordinated movements, dances and games that require large spaces such as taking, sparrow hawk, castle, scalp, hunting with numbers. They are all easily proposable, utilitarian and concrete activities that, if well used, will give positive results in the improvement of the great cardio-circulatory and respiratory organic functions (functional aspect), in the harmonic development of the skeleton, muscles and joints (structural appearance), in improving motor conditional qualities, in the improvement of the motor qualities conditional and coordinative (utilitarian aspect) and in the capacities of adaptation demanded from living in contact with the nature and from a remarkable effort of will and active participation (moral, psychic and characteristic aspect).

Outdoor school spaces may be adequately equipped and maintained to provide spaces for safe and engaging motor activity. Another specific aspect of Outdoor Education are the Outdoor Adventure Education (OAE). The potential benefits of the OAE are as follows (Ewert, 1987, p.24): Psychological such as Security; Selfeffectiveness; Well-being; Self-awareness; Social as Cooperation; Respect for others; Communication; Friendship. Educational such as New knowledge; Outdoor techniques; Problem solving ability; Environmental awareness; Physicists such as Enable; Strength; Balance; Form. The reported research observe the activities typically conducted in adventure programs (OAE), in this model, the change generated by the OAE helps to create a constructive state of anxiety (Walsh \& Golins, 1976) encouraging the individual to exit from their comfort zones entering an area of challenge, challenge, positive competition. Many studies have shown how this combination of challenge, mastery and competence, success, can drive the growth of participants (Witman, 1995) in a simple and spontaneous way (Sgrò, \& Lipoma, 2015).

These adventure programs (OAE) indicate how the challenges present in these activities and experiences must be holistic, encompassing all the components of the individual, mental, emotional and physical (Walsh \& Golins, 1976). Every society through the education it defines imposes on the individual a determined use of his own body (Le Boulch, 1971, p.54). To better explain the study of movement in the scientific field it seems necessary to emphasize some key concepts. "Deepening the bodily expression, the student finds himself struggling with the elements common to all the arts: time, space, energy. By doing so, he becomes aware of contrasts and nuances, feels pleasure in the refinement of detail: he will be attentive to silence, will be impressed by the quality of a shape, a volume, moved by the perfection of a movement. So, it will be refined intuition and stimulated creativity" (Martinet, 1992. p.22). 


\section{CONCLUSION}

In a society like ours, concentrated in depersonalized urban agglomerations, the return to nature is widely felt. The natural environment, where possible, is to be considered a valid support to the gym especially now. Children have the physical and spiritual need to live and move even in contact with nature. Motor and sports education at school: it has its own specific teaching, which cannot disregard the fact of being a practical discipline, which acts on the field in relation to others (Tortella, \& Fumagalli, 2017).

The environment, in this sense, in addition to taking on the central role of organizer of such exchanges, "acts as a space-time in which to place itself and becomes an interpretative key, a cognitive and operational structure of the entire system" (Rossi, 2009, p.61). "There may be many and very different spaces between them other than the classroom in which to carry out educational activities: libraries, gardens, gardens, woods, multimedia spaces, workshops. [...] In an almost osmotic process, the classroom, understood as a space of action and knowledge, should become a diffused environment and represent only one of the many places of learning" (Strongoli, 2019. pp.437-438). "Critical (guided) reflection on teaching practices appears to be a particularly effective methodology. Teachers often complain about the lack of places for reflection, discussion and exchange, often because of too many commitments. It is then a question of organising working and research groups of teachers (guided by experts) who critically reflect on teaching practices and disciplinary content' (Fiorucci, 2015. p.64). The child, especially if very young, takes possession of space through movement and exploration.

The child is at the centre and everything around it is organized in function and it is after having acted the space that fills it with meanings, the space has lived emotionally, the lived extends or contracts, moves away or approaches, is empty or full depending on the emotions and actions (Bobbio, \& Traverso, 2016). For the adult the space is mainly a geometric space, homogeneous, a distance measurable and well defined, classifiable, in which the objects have a precise location and function. The adult knows the space by taking root, taking possession of it by filling it with objects that are significant to him, transforming it into his own space of identity (lori, 1996).

In conclusion, we can define motor learning can only take place if the activity is presented in a space and in a codified and programmed time, both at school and in extra-curricular places, in an indoor and outdoor environment, presented by experienced and trained teachers (Vago, et al., 2015a) supported by suitable tools and instruments in step with the times.

\section{AUTHOR CONTRIBUTIONS}

D.C.: Conceptualization, Methodology, Writing-Review \& Editing, and Supervision and in particular paragraphs n. 2; 4. R.C.: Conceptualization, Literature Analysis, Writing-Original Draft Preparation and in particular paragraphs n. 1. R.S.: Conceptualization, Literature Analysis, Writing-Original Draft Preparation. and in particular paragraphs n. 5. F.C: Conceptualization, Investigation, Writing-Review \& Editing, and Supervision. and in particular paragraphs n. 3. All authors have read and agreed to the published version of the manuscript.

\section{REFERENCES}

Alberici A. (2002). Imparare sempre nella società della conoscenza. Milano: Mondadori.

Bobbio A., Traverso A. (eds.) (2016). Contributi per una pedagogia dell'infanzia. Pisa: Ets. 
Calvesi A., Tonetti A. (1998). L'attività motoria e l'educazione. Milano: Principato.

Caprara, G. V., Steca, P., Gerbino, M., Paciello, M., \& Vecchio, G. M. (2005). Looking for adolescents' well-being: Self-efficacy beliefs as determinants of positive thinking and happiness. Epidemiologia e Psichiatria Sociale, 15, 30-43. https://doi.org/10.1017/S1121189X00002013

Carpi L. (2017). Educare in natura. Strumenti psicomotori per l'educazione all'aperto. Trento: Erickson.

Casolo F., (2019). Scuola primaria: spazi ambientali e temporali per l'educazione motoria. Pedagogia Oggi / Rivista SIPED / anno XVII / n. 1/2019. P. 493-507. ISSN 2611-6561 (c Pensa MultiMedia Editore, Lecce-Brescia. https://doi.org/10.7346/PO-012019-33

Casolo F., Coco D., (2019). Educazione motoria nella scuola primaria: Quali competenze per il docente? In Casolo F., (a cura di) L'Educazione Motoria e scuola primaria. Formazione \& Insegnamento. Rivista internazionale di Scienze dell'educazione e della formazione, XVII - 3s - 37-46, Lecce: Pensa MultiMedia Editore.

Casolo, F., Coco, D., Frattini, G., Vago, P., \& Casolo, A. (2019). Effective teaching competence in physical education. The Journal of Physical Education and Sport, 19 (Suppl. 5), 1806-1813.

Ceciliani A., (2019). Spazi e attività per una scuola innovativa. Formazione \& Insegnamento. XVII - 2 2019. P.115-129. @ Pensa MultiMedia - ISSN 2279-7505 on line.

Ceciliani A., Bortolotti A. (2013). Outdoor Motor Play: Analysis, Speculations, Research Paths. Center for Educational Policy Studies Journal, 3, 3.

Ceppi, G. Zini, M., 1998, Bambini, spazi, relazioni-metaprogetto di ambiente per l'infanzia, Reggio Children e Comune di Reggio, Reggio Emilia.

Coco, D., Tortella, P., \& Casolo, F. (2020). Alla scoperta della resilienza e la correlazione con le attività motorie e sportive. Formazione \& Insegnamento. Rivista internazionale di Scienze dell'educazione e della formazione, 18(3), 50-66.

Coco D., (2016). Sports and physical activities as an educational teaching model to support the family in the free time. In M. Saenz De Jubera, E. Isidori, (a cura), Ocio y familia: contextos educativos (pag. 74-94) Roma: Edizioni QUAPEG. ISBN: 9788822880574. https://doi.org/10.5281/zenodo.220888

Coco D., (2015). Educare alla corporeità nel rapporto col reale, tra esteriorità ed interiorità. Formazione \& Insegnamento XIII - 2 - 2015 ISSN 1973-4778 print - 2279-7505 on line.

Coco, D. (2014). Pedagogia del corpo ludico-motorio e sviluppo morale. Roma: Anicia.

Damiano E. (ed.) (2013). La mediazione didattica. Per una teoria dell'insegnamento. Milano: FrancoAngeli.

D'Elia, F. (2019) The training of physical education teacher in primary school. Journal of Human Sport and Exercise, 14, pp. S100-S104. https://doi.org/10.14198/ihse.2019.14.Proc1.12

Ewert, A. (1987), Research in outdoor adventure: overview and analysis. In Bradford Papers Annual. Woods Outdoor Education Center, Indiana University 1987 No.2 pp.15-28.

Farnè R., Agostini F. (2010). Outdoor education: l'educazione si-cura all'aperto. Parma: Junior Spaggiari.

Ferrante, A., \& Sartori, D. (2011). Per un'analisi del dispositivo strutturale dell'educazione sportiva. CQIA 54-65.

Fiorucci M.. (2015). La formazione interculturale degli insegnanti e degli educatori. Formazione \& Insegnamento XIII - 1 - 2015. ISSN 1973-4778 print - 2279-7505 on line.

Fischetti, F., Latino, F., Cataldi, S., Greco, G. (2020) Gender differences in body image dissatisfaction: The role of physical education and sport. Journal of Human Sport and Exercise, 15 (2), pp. 241-250. https://doi.org/10.14198/ihse.2020.152.01

Foucault M. (1975). Surveiller et punir. Naissance de la prison. Paris: Editions.

Frabboni, F., 1992, La scuola dell'infanzia - la prima frontiera dell'educazione, Firenze: La Nuova Italia. Gallimard (1976). (trad. it. Sorvegliare e punire: nascita della prigione, Torino: Einaudi.

Gennari M. (1997). Pedagogia degli ambienti educativi. Roma: Armando. 
Haga, M., Tortella, P., Asonitou, K., Charitou, S., Koutsouki, D., Fumagalli, G., \& Sigmundsson, H. (2018). Cross-cultural aspects: Exploring motor competence among 7-to 8-year-old children from Greece, Italy, and Norway. Sage open, 8(2), 2158244018768381. https://doi.org/10.1177/2158244018768381

Hebert G. (1936). Education physique, virile et morale par la mèthode naturelle. Paris: Vuilbert.

laschi, G., (1995). Le ragioni del corpo, dall'educazione fisica all'educazione motoria, Palermo: Palumbo. lori V. (2018). II sentimento dell'abitare. In L. Fabbri (ed.), Educare agli affetti. Roma: Armando.

Isenberg, J. P.; Jalongo, M. R. (1997). Creative Expression and Play in Early Chilhood. Prentice Hall, New York.

Le Boulch, J., (1971). Verso una scienza del movimento umano. Roma: Armando.Lelli.

Lipoma, M. (2014). Educazione Motoria. Lecce: Pensa Multimedia.

Galvani C., Milani M., Coco D., Vago P., Codella R., Rucco D., Codrons E., Vandoni M. (2017). Effectiveness of a physical education program on children's physical fitness. Sport Sciences for Health. Volume 13-Supplement 1 - September 2017. p. S62. 13. Springer. ISSN: 1824-7490 Print; ISSN: 1825-1234 Electronic.

Malaguti, L., 2004, Una carta per tre diritti, Bambini, 20(2), 16-17.

Malaguti, L., 2010, I cento linguaggi dei bambini. L'approccio di Reggio Emilia all'educazione dell'infanzia, Edizioni Junior, Bergamo.

Martinet, S., (1992). La Musique del corpo: manuale di espressione corporea (Vol. 20). Trento: Erickson. Miljak, A., 2009, Življenje djece u vrtiću, SM Naklada d.o.o., Zagreb.

Ministero della Pubblica Istruzione, (2007). Indicazioni per il curricolo. Per la scuola dell'infanzia e per il primo ciclo d'istruzione. Roma: Tecnodid.

Monti F., Farné R., Crudeli F., Agostini F., Minelli M., Ceciliani A. (2017). The role of Outdoor Education in child development in Italian nursery schools. Early Child Development and Care Journal. https://doi.org/10.1080/03004430.2017.1345896

Montesano, P. (2018). Monitoring and upgrading of coordinative capacities of young athletes practicing handball. Journal of Physical Education and Sport, Supplement Issue 1, 465-468.

Montella, M., Ceciliani, A., Morsanuto, S., Federici, A., Altavilla, G. (2019) Development of motor skills applied to basketball in the developmental age. Journal of Human Sport and Exercise, 14 (Proc4), pp. S835-S840. https://doi.org/10.14198//hse.2019.14.Proc4.46

Notarnicola, A., Vicenti, G., Fischeti, F., Laricchia, L., Guastamacchia, R., Tafuri, S., Moreti, B. (2012) Improved mental representation of space in beginner orienteers. Perceptual and Motor Skills, 114 (1), pp. 250-260. https://doi.org/10.2466/03.04.11.PMS.114.1.250-260

Parricchi M. (2019). Approccio pedagogico alla progettazione di ambienti educativi. Pedagogia Oggi / Rivista SIPED / anno XVII / n. 1 / 2019. ISSN 2611-6561 @ Pensa MultiMedia Editore, Lecce-Brescia. https://doi.org/10.7346/P0-012019-26

Perla L. (2002). Comunicare. In Laneve C. (a cura di). Vivere in città. Linee di pedagogia urbana (pp. 27 57). Brescia: La Scuola.

Pignato, S., Coppola, R., \& Manzo, G. (2016). Valutazione comparativa di modelli di insegnamento di educazione fisica. Formazione \& Insegnamento, XIV, 1, Supplemento, 133-146.

Rossi P. G. (2009). Tecnologia e costruzione di mondi. Roma: Armando.

Sgrò, F., Mango, P., Pignato, S., Schembri, R., Licari, D., \& Lipoma, M. (2017). Assessing standing long jump developmental levels using an inertial measurement unit. Perceptual and motor skills, 124(1), 21-38. https://doi.org/10.1177/0031512516682649

Sgrò, F., \& Lipoma, M. (2015). Can An Exergames Training Program Improve The Jump For Height Skill In Childhood. Turkish Online Journal of Educational Technology, Special Issue for INTE 2015, 8996. 
Sgrò, F., Nicolosi, S., Schembri, R., Pavone, M., \& Lipoma, M. (2015). Assessing vertical jump developmental levels in childhood using a low-cost motion capture approach. Perceptual and motor skills, 120(2), 642-658. https://doi.org/10.2466/10.PMS.120v12x7

Simonetti, C., (2013). Educare la persona al movimento: dalle attività motorie alla pedagogia della corporeità e dello sport. Bari: Insieme.

Strongoli, R.C. (2019). Quando gli spazi educano. Ambienti d'apprendimento per unadidattica all'aperto. Pedagogia Oggi. XVII (1), 431-444.

Tortella, P., Haga, M., Ingebrigtsen, J. E., Sigmundsson, H., \& Fumagalli, G. F. (2019). Comparing free play and partly structured play in 4-5-years-old children in an outdoor playground. Frontiers in public health, 7, 197. https://doi.org/10.3389/fpubh.2019.00197

Tortella, P., \& Fumagalli, G. (2017). The effect of teaching methodologies in promoting physical and cognitive development in children. Physical Activity and Educational Achievement: Insights from Exercise Neuroscience, 297. https://doi.org/10.4324/9781315305790-17

Tortella, P., Haga, M., Loras, H., Sigmundsson, H., \& Fumagalli, G. (2016). Motor skill development in Italian pre-school children induced by structured activities in a specific playground. PLoS One, 11(7), e0160244. https://doi.org/10.1371/journal.pone.0160244

Vago, P., Coco D., Colombo, L., Frattini, G., Gatti, M., Casolo, F. (2015b). Personological aspects in Sport Science students and Physical Education teachers: Sport Sciences for Health. Volume 11Supplement 1- September 2015. P. S15. Springer. ISSN: 1824-7490 Print; ISSN: 1825-1234 Electronic.

Vago, P., Coco D., Colombo, L., Frattini, G., Gatti, M., Casolo, F. (2015a). Values orientation in Sport Science students and Physical Education teachers: Sport Sciences for Health. Volume 11 Supplement 1- September 2015. Springer. P. S90 ISSN: 1824-7490 Print; ISSN: 1825-1234 Electronic.

Walsh, V., \& Golins, G. L. (1976). The exploration of the Outward Bound process. Denver, CO: Colorado Outward Bound School.

Weyland B., Stadler-Altmann U., Prey K., Galletti A. (eds.) (2019). Scuole in movimento. Milano: FrancoAngeli.

Weyland B., Attia S. (2015). Progettare scuole Tra pedagogia e architettura. Milano: Guerini.

Witman, J. P. (1995). Characteristics of adventure programs valued by adolescents in treat-ment. Youthin the 1990s, 4, 127-135.

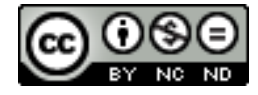

This work is licensed under a Attribution-NonCommercial-NoDerivatives 4.0 International (CC BY-NC-ND 4.0). 